DOI: https://doi.org/10.11144/Javeriana.umed59-4.infr

\title{
Mental Health in the Attention Models for Juvenile Offenders. The Cases of Colombia, Argentina, United States and Canada
}

\section{La salud mental en los modelos de atención de adolescentes infractores Los casos de Colombia, Argentina, Estados Unidos y Canadá}

Received: July 312017 | Accepted: April 202018

\author{
Juliana Villanueva Congote \\ Pontificia Universidad Javeriana, Colombia \\ María Camila Jaramillo Bernal ${ }^{\mathrm{a}}$ \\ Pontificia Universidad Javeriana, Colombia \\ Esteban Sotomayor Carreño \\ Pontificia Universidad Javeriana, Colombia \\ Catherine Gutiérrez Congote \\ Harvard Medical School, Estados Unidos \\ Angélica Torres-Quintero ${ }^{1}$ \\ Pontificia Universidad Javeriana, Colombia
}

\footnotetext{
a Correspondence: camilajaramillobernal@gmail.com

1 Assistant Professor of the Public Health Institute, Pontificia Universidad Javeriana, Bogotá, Colombia. Psychologist, Master's Degree in Social Policy
}

How to cite: Villanueva Congote J, Jaramillo Bernal $\mathrm{MC}$, Sotomayor Carreño E, Gutiérrez Congote C, Torres-Quintero A. Mental health in the attention models for juvenile offenders: The cases of Colombia, Argentina, United States and Canada. Univ. Med. 2018;59(4). doi: https://doi.org/10.11144/ Javeriana.umed59-4.infr

\begin{abstract}
Objective: To investigate how mental health is understood and approached in the attention models of detention centers for the convicted underage population in Argentina, Colombia, United States and Canada. Methodology: A literature search was conducted using the following key words: adolescence, mental health, juvenile justice, juvenile delinquency, risk factors, and interventions. Searches were done through the search engine Pubmed. Additionally, public institution websites for each country were consulted. Conclusions: Juvenile delinquency is now understood as a multi-factorial phenomenon with multiple areas of intervention within which economic, domestic and social factors are considered relevant, since these favor the development of criminal behavior. A similarity was found between Colombian and Argentinian systems; both are based on restorative justice that seeks reparation and not punishment; which is why there are no punitive measures. When comparing Canada and the United States, it can be seen that Canada is more similar to Latin-American countries than to the United States, given that the latter uses punitive measures focused on the offender.
\end{abstract}

Keywords

adolescence; mental health; juvenile justice; juvenile delinquency; risk factors; and interventions.

\section{RESUMEN}

Objetivo: indagar cómo se entiende y aborda la salud mental en los modelos de atención de la población infantil infractora en los centros de detención de Argentina, Colombia, Estados Unidos y Canadá. Metodología: se buscó literatura sobre el tema empleando las palabras clave adolescencia, salud mental, justicia juvenil, delincuencia juvenil, factores 
de riesgo e intervenciones. El buscador empleado para la consulta fue Pubmed. Adicionalmente, se utilizaron páginas de instituciones públicas de cada país. Conclusiones: la delincuencia juvenil se entiende ahora como un fenómeno multifactorial con múltiples áreas de intervención dentro de las cuales cobran relevancia las condiciones económicas, familiares y sociales, puesto que propician la aparición de conductas delictivas. Se encontró una similitud entre los sistemas de Colombia y Argentina, pues ambos se basan en una justicia restaurativa que busca reparación y no castigo; por ende, no hay medidas punitivas. Al comparar Canadá y Estados Unidos se ve que Canadá se parece más a los países latinoamericanos que a Estados Unidos, puesto que este último usa medidas punitivas centradas en el victimario.

Palabras clave

adolescencia; salud mental; justicia juvenil; delincuencia juvenil; factores de riesgo e intervenciones.

\section{Introduction}

This paper analyzes the documents that address the subject of mental health within the care models for the juvenile delinquent population in Colombia, Argentina, the United States and Canada, in order to present the particular characteristics of conception and approach of said intervention models. Specifically, we address the policies proposed by the detention centers of each country, the risk factors considered in each model, the processes of reintegration into the community, as well as the regulatory frameworks and the concept of mental health on which each model is based.

\section{Methodological design}

A search of literature on the subject was carried out, with a time window of 18 years, which included documents from 1999 to the end of 2017. Scientific and press articles, as well as gray literature (laws, regulations, informative brochures, reports and book reviews) were chosen. To select the scientific articles, the Pubmed database was used. In addition, the websites of public institutions such as the Colombian Family Welfare Institute, Youth.gov, of the United States, the Department of Juvenile Justice of Canada, and Juvenile Justice of Argentina were reviewed.
Of the 63 documents found, 40 were selected. The criterion of eligibility was texts that presented an understanding of mental health and its approach in the different care models for the juvenile delinquent population of the aforementioned countries.

Of this group of documents, 21 are related to the case of Colombia. Among these are informative brochures of the Colombian Family Welfare Institute, a paper that discusses the positive and negative aspects of the Code of Childhood and Adolescence, an article on the political and social factors of juvenile delinquency and the laws that regulate the Colombian Juvenile Criminal System.

The case of Colombia was also documented from the review of 9 scientific articles. Of these, 5 are qualitative studies that explore the social representations of mental health in youths with behavioral disorders (Medellín and Manizales); the homicidal behavior of youths (Bogotá); the profile of the juvenile delinquent population, as well as the risk factors, expectations about programs and attention strategies (Barranquilla); and the family, social and educational experiences of juvenile offenders (eastern Antioquia).

Likewise, we reviewed a case-control study carried out in the city of Medellín, which uses screening measures to detect signs and symptoms of behavioral disorders in young men; a sociolegal investigation carried out in the city of Barranquilla that analyzes the public policies developed at the municipal level to prevent and punish juvenile delinquency; a systematic review of literature, which explores the experiences of victimization in the context of the armed conflict and certain criminal behaviors as survival strategies, and, finally, a narrative review on risk factors for juvenile violence and homicide.

On the other hand, to structure the case of Argentina, four documents were reviewed, among them Law 13298 of 2005 on the promotion and comprehensive protection of children's rights, established for juvenile offenders; the National Mental Health Law; a follow-up report on the implementation of the Convention on the Rights of the Child, 
produced by the Ministry of Justice, Security and Human Rights of the Nation, and a mixed study conducted in the province of Buenos Aires, which analyzes the operation of the juvenile justice system.

The documentation of the United States Juvenile Criminal System was made from the review of 12 documents and the website of the United States Department of Justice. Within the referenced documents is a legislative report that emphasizes the need for mental health care in juvenile detention centers; a press article that analyzes the case of a young man sentenced to life imprisonment, and a newspaper article about therapeutic alternatives for youths who are in detention centers.

Similarly, 6 scientific articles were included, 3 of which are systematic reviews that analyze the correlation of variables such as delinquency, mental health/illness and learning problems; the relevance of including mental health services within the model of justice, and the effectiveness of preventive programs.

Three other quantitative studies analyze the problem of drug abuse and the proportion of young consumers who receive mental health services within the system, as well as the results of the implementation of mental health screening in detention centers of the state of Indiana. A study was included that analyzes the offer of mental health services to detained youths, and another that proposes the implementation of a model of care within the juvenile justice system.

Finally, to document the case of Canada, the Department of Justice website was consulted, as well as a document produced by the Ministry of Justice and the Office of the Attorney General, which describes the Juvenile Criminal System. In addition, an article was reviewed that suggests strategies for the prevention of juvenile delinquency in the Canadian population, produced in the province of Quebec with youths between 12 and 17 years old in conflict with the law.

\section{Results}

Based on the review of the selected documents that deal with care models for the juvenile delinquent population in Colombia, Argentina, the United States and Canada, we present an analysis organized in 5 parts. The first part offers a general overview of the characteristics of the intervention models implemented in each country; the second part focuses on showing the conceptions on the phenomenon of juvenile delinquency; the third explores the ideas of mental health on which these models are based, and their relationship with the dissocial behavior; the fourth one analyzes the way in which the dimension of mental health is understood within the intervention models, and the last one presents the types of mental health interventions adopted in the models.

\section{Criminal systems for juvenile offenders}

\section{Colombia}

The Juvenile Justice System (SRPA, by its Spanish acronym) of Colombia is based on the concept of comprehensive justice, rather than punitive justice. It is carried out through protective, pedagogical and restorative procedures and sanctions whose main objective is restoration of rights and the social inclusion of the imputable adolescent (1). In 2006, Law 1098, called Code of Childhood and Adolescence, was created. According to its first article, this law aims to "guarantee children and adolescents their full and harmonious development so that they grow in the bosom of the family and the community, in an environment of happiness, love and understanding" (2). In its second article, the law contemplates the SRPA and the special procedures for children and adolescents who are victims of crimes (2).

Regarding the SRPA, a paradigm shift can be observed. It goes from having the delinquent adolescent as the only subject of the process, to involving the victims and the family environment of the prosecuted individual (1). In addition, the 
juvenile offender is no longer considered to be in an irregular situation and that he/she is not criminally liable (Article 165 of Decree 2737 of 1989), and is considered as the result of multiple conditions that generate conflicts and that lead him/her to committing criminal acts (3).

The System distances itself from punitive justice and understands crime as a social conflict that causes damages that can be restored (4). This restorative justice is based on a process in which all those involved in a crime are participants, and collectively resolve the consequences of the action of the juvenile offender. The main forms of reparation are restitution, compensation, rehabilitation, satisfaction and the guarantee of non-repetition (5). Additionally, assistance measures are considered in order to restore the rights of those affected in both their mental and physical health (1).

At the moment, the SRPA deals with juvenile offenders by firstly promoting deinstitutionalization, in order to generate noncustodial strategies, since this must happen only in exceptional cases (1). In this last instance, the system proposes an institutional and behavioral transformation in order to understand minors as subjects responsible of rights who are active citizens, responsible for a damage that they must repair it (1).

\section{Argentina}

In the city of Buenos Aires, Argentine Republic, the juvenile criminal system is oriented towards responsibility and reparation. It is based on two aspects: 1) in a framework to provide alternative solutions to conflicts and 2) in a declaration of criminal responsibility, which results in the application of a penalty (6). The process of accountability seeks that the young person can assume his behaviors in order to modify those actions that harm him, or reflect on the offence committed and its implications on his life and on that of the victim (6).

With regard to reparation, the word "renew" is alluded to, with the ideal of amending the damage caused. While it is impossible to erase the aggression, it is true that justice must allow the ways to repair both material and subjective damage (6). To this end, the model adopts two types of measures: on one hand, non-custodial measures, which must be accompanied by comprehensive and intersectoral public policies that guarantee economic, social and cultural rights for children and adolescents and their families. On the other hand, it takes into account the jurisdictions of the country and the respective local protection systems, together with a critical analysis of the legal and psychosocial interventions that are carried out from different areas (6).

Finally, the Argentine system states that it is necessary for the victim to be face to face with the offender so that he/she can understand the seriousness of his/her action. Although the active participation of the community in the resolution of the conflict may be of great value, this is only encouraged insofar as its presence does not affect the young person (6).

Law 13298 of 2005, which establishes in Article 31 the application of non-custodial sanctions to children who violate the law, in its Article 36 stipulates that in no case a detention may be ordered through police agencies of a child who had not been deprived of freedom of movement by order of the competent judge and in the context of a case for infraction of the criminal law. This law protects the premises raised by the International Convention on the Rights of the Child (7).

With the above it is observed that the figure of the juvenile judge disappears, as well as that of their professional teams, so the powers that the juvenile judges had by that time (1983) are fragmented. From this a juvenile criminal system was created that seeks the verification of the punishable act and the identification of its authors. Since then, the system has been integrated by guarantee judges, liability courts, prosecutors and public defenders (6).

Criminally liable youth are those who having committed a crime are between 16 and 18 years of age. In serious cases, it is admitted that they go to preventive detention, which can last 6 months 
and, in exceptional cases, one year (4). The system of Buenos Aires, Argentina, establishes as not criminally liable children under 16 years old or those who for different reasons have not been able to fully understand that their actions violate the law. The system seeks the coordinated intervention of specialists that from different environments of the State are enabled to work with the youths and their environment (6).

\section{United States}

The United States juvenile criminal system has undergone transformations over time, backed by legislative changes. It went from the "surveillance model", in which regardless of the ethnicity, sex and age of the offender, the subjects were punished for the crimes committed against a society that sought retribution, to a formative model at the beginning of the twentieth century, focused on the protection of minors' rights and needs, which left aside the punitive processes of the adult system. In this program the inmates were encouraged to take classes, do physical exercise, establish links and receive vocational training in order to get employment after leaving prison. Here the objective became to achieve rehabilitation, and not the application of punitive measures (8).

During the decade of the eighties of the twentieth century, given the marked incidence of juvenile delinquency, the objective of the system was once again the protection of the community. In the 1990s, more than half of the country agreed that juvenile delinquents should be tried in criminal courts for adults and that more punitive laws be imposed (9).

Currently, detention centers in all states are used primarily for temporary arrests. However, the people in charge of the juvenile courts may decide to leave the young person in detention while he/she is being prosecuted. In general, juvenile offenders are deprived of their liberty for longer periods if there are reasons to believe that they are a threat to the community (10).

Finally, it is essential to bear in mind that the United States has a federal government, which is why each state defines which youths are governed by a juvenile court. The foregoing varies between states, where the upper limit for said jurisdiction is between 15 and 17 years of age (10).

\section{Canada}

For more than a century, this country has had laws to address juvenile justice, and since then there have been 3 laws that regulate it. The first is the Juvenile Delinquents Act, which was in effect between 1908 and 1984. It was replaced by the Young Offenders Act, whose validity ended in 2003, date on which the Youth Criminal Justice Act came into effect (11).

The current system seeks to protect the population in general, holding youths responsible for their actions, applying measures that are in accordance with the seriousness of the criminal act committed and that seek to promote the rehabilitation and social reintegration of youths, unlike the system of adults, since it is assumed that there is a diminished moral culpability or power (11).

Nowadays, federal and territorial governments share responsibilities with regard to juvenile justice. The federal government is responsible for formulating criminal laws; while the provinces and the different territories are responsible for their application (12).

The Department of Justice is in charge of dealing with criminal acts committed by youths between 12 and 17 years of age, since it is responsible for the activities carried out in the judicial system and is responsible for managing the funds allocated to the different institutions. Such attributions allow them to collaborate with the provinces and territories and deliberate about programs and services for youths who are in conflict with the law (11).

\section{How is juvenile delinquency explained?}

In order to determine how to explain the phenomenon of delinquency in Colombia, we explored several points of view; for this, we compared what is established by the State 
with the opinion of different authors who have conducted research and field studies on the subject.

Based on this, we found that both the Colombian State and multiple authors consider that delinquency is a multifactorial phenomenon that presents a similarity in the explanation of the phenomenon and its causality. Regarding the State, the SRPA proposes a list of the main characteristics that describe young offenders. This characterization was divided into three main levels: the first is the sociodemographic level, which describes young males from low social strata; the second is the personal-psychological, where the conditions of abuse, exploitation and consumption of psychoactive substances are found, and, finally, there is the family level, which includes families immersed in violence, generators of risk environments, among others. In addition, it provides a list of problems that juvenile offenders have suffered in childhood, with all forms of violence, victims of the armed conflict and child abuse, together with the consumption of psychoactive substances (1).

Like the Colombian State, several authors propose various risk factors for a young person to become a delinquent. According to Gabriel Castellanos et al. (13), these factors are determined by conditions of serious family violence, to which is added being a male, having a history of behavioral disorders, hyperactivity, high levels of irritability or suicide attempts, belonging to gangs, being on the street much of the time and abuse of alcohol or psychoactive substances, carrying weapons, low schooling and marked poverty conditions. In addition, it is concluded that being a victim of violence is another important risk factor to become a violent criminal.

Now, an important issue when talking about mental health in Colombia is the armed conflict, which has lasted more than 50 years in the country. Campo-Arias et al. (14) talk about the conditions in which the victims of the displacement caused by the armed conflict live. Unemployment and social exclusion are conditions that make them prone to be in circumstances that can lead them to violate the law, since the above prevents the collective emotional well-being of the population (14).

This stance on the armed conflict is not only considered by the mentioned authors, but also by the Colombian State. The SRPA refers to a special group, which is called de-linked, understood as all the children and adolescents whose rights were snatched away and who were recruited to participate in said conflict, so they are considered more victims than aggressors (1).

On the other hand, Liberos et al. (15) state that juvenile delinquency in the city of Barranquilla is born from the fact that children and youth do not go to school. In addition, they contemplate an innovative fact in the matter, which is that almost no free time is devoted to extracurricular activities, such as sports, recreation and culture. These authors mention that this situation is the Government's fault, because it is not looking for ways to provide these spaces. Because of this, children spend a lot of time on the streets, especially at night, which makes them more prone to consume psychoactive substances, to join criminal gangs and break the law. To the above, the authors add that, at the moment, the efforts of public policies, laws and strategies of local and departmental authorities aimed at the education of these young people are invisible to citizens (15).

Thus, criminal behavior can be understood as a result of family, social and individual relationships (16). Additionally, some authors suggest that a central element in the recidivism and continuity of criminal acts is the power of stolen money. Beyond being an element that facilitates satisfying basic needs, it is an instrument that allows minors to use power as a means to build a collective and individual identity.

In a case-control study conducted in schools in the city of Medellín where male youths from strata 1 to 4 were studied, mothers were questioned about their children. The study showed that behavioral disorders in young people are the result of the violent environment in which they live from an early age, where they witness massacres, disappearances, kidnappings and homicides (17). 
On the other hand, Mónica Acosta Amaya (18) suggests that the lives of juvenile delinquents are affected by behavioral problems from an early age, and are not helped in time by the people and institutions responsible for the integral development of young people. It is argued, then, that these behaviors are nothing more than the perpetuation of certain behavioral traits that were not attended to in time and that, added to others, give rise to criminal behavior.

As with Colombia, the phenomenon of juvenile delinquency in Argentina is compared, where great similarities were found in what was considered by the State and by various authors of the country in question. For the State there are two major factors related to the development of juvenile delinquency: the first is the process of identity construction and the second is autonomy. In the first point the construction of the identity and the psyche of a teenager is explored, where this is influenced from an early age by the family, social and economic environment in which he/she grows. Now, specifically for the country, they consider that violent acts, poverty, marginalization and abandonment have led adolescents to not be able to build their identity based on ethics and values (19).

Regarding the conception of autonomy, the State considers that adolescence is a critical period; however, if this whole process of gain is not limited or controlled to some extent by a superior subject, young people will grow up with a feeling of egocentricity and total freedom. Within the unlimited autonomy, it has been noted that the father figure has suffered a fall, due to impunity and social fragmentation. This aspect leads to justice having to symbolically replace the function of the father. To this, the organic and moral composition of the individual must be added, since external and internal factors affect the behavior of the adolescent, given that the behavior also depends on the tensions present in the social structure (19).

Additionally, for the State, when there is a juvenile offender, it is necessary to take into account several aspects, such as the seriousness of the crime, the damage caused and the will to repair it. However, this is not enough to understand the whole conflict that the juvenile offender live in a situation of disadvantage or social vulnerability (19).

Now, Jorge Folino (6) considers that this phenomenon is a multifactorial fact for the system, since the minor has not completed his training as an adult, so he/she is affected by sociocultural influences that are present in his/her development. Among these are family, educational and peer influences. He also states that parents who provide less attention and emotional warmth to their children tend to have adolescents with more aggressive behaviors, accompanied by criminal acts, and a relationship between gang membership and an increase of juvenile delinquency is observed.

On the other hand, the United States system takes into account the relationship between substance abuse and criminal recidivism, so that the country's juvenile justice agencies are positioned to significantly impact public health through the identification and early attention of said behaviors (20).

According to the article DelinquentVictimYouth-Adapting a Trauma-Informed Approach for the Juvenile Justice System (21), people who have been victims of any type of violence or trauma in their childhood are prone to commit criminal acts in the future. Therefore, the author of this article establishes a clear relationship between the history of violence and traumas suffered and the development of criminal behavior. Due to this, he proposes that those who have been victims of multiple mistreatment and abuse be subjected to evaluations and services to prevent permanent emotional, physical, psychological and social damage. In this way, the generation of possible criminal acts is avoided.

Similarly, Underwood and Washington (9), authors on the subject, establish that there is a relationship between certain types of mental disorders and violent behaviors. They mention that the risk of committing violent acts is increased by emotional, attention or hyperactivity disorders, due to their great emotional impact and personal dysregulation. 
Affective (depression), psychotic and anxiety disorders and disruptive behavior are the ones that have been most related to the development of violent behavior, the latter being the most mentioned. In the United States, there has been a high prevalence of depressive disorders (10-25\%) in the juvenile criminal system, which is often accompanied by an irritable mood that increases the risk of aggressive responses toward others.

In contrast, according to the Youth Criminal Justice Act of Canada, which is consistent with the stipulations of the authors of that country, the phenomenon is attributed to the nonimplementation of the Parliament's statements, which show juvenile delinquency as a multifactor problem that assigns responsibility both to society and the Government (12).

Additionally, in that country delinquency is attributed to the abuse of psychoactive substances, which is why the "National AntiDrug Strategy" is found, which seeks to provide help to reduce the demand for illicit drugs in order to address the crimes associated with substance abuse. The strategy is based on the prevention, treatment and confrontation to deal with the abuse of psychotropics (12).

\section{How is mental health and its relation with dissocial behavior understood?}

In Colombia, a concordance was found between what the State proposes and what the authors understand about mental health and its correlation with dissocial behavior. Taking into account Law 1616 of 2013, the system states that mental health is the ability of the individual to deploy all his/her mental, emotional and cognitive spheres in a way that allows him/her to interact with the environment in an appropriate way (22).

Due to this, for the State, the behavioral disruptive phenomenon has a multifactorial origin, which is why it considers pedagogical interventions in order to provide social inclusion options to the young people involved in the SRPA, in order to favor a responsible and autonomous exercise of citizenship $(23,24)$.
What has been said is similar to what Betancur et al. (17) state; they consider that given that mental health is constituted from the multiple experiences of the subjects in the different daily scenarios, it escapes the objective condition posed by the purely scientific practice, and harbors multiple risk factors that vary according to the development environment of the individual.

On the other hand, Vergara Quintero (25) concludes that the concept of mental health of young people is very broad and covers the social, family and mental spheres; for this reason, for the youths the relationship with others is critical, which leads us to think that if this type of values can be worked on in the youths involved in the system through education, recidivism could be avoided more efficiently.

Now, based on the aforementioned, a discrepancy was found between what was established by the State and the way in which the juvenile criminal system is actually addressed. According to Nicolás Uribe Aramburo (26), despite the fact that jurisprudence establishes the various factors that influence dissocial behavior, it leaves aside the psychological explanation of the behavior of these youth, who are frequently described according to the standards established in the law without taking into account their mental structure.

Comparatively, Argentina understands mental health as a multifactorial phenomenon in which the psyche is influenced by historical, socioeconomic, psychological, biological and cultural factors. Due to this, the system seeks to preserve mental health through social construction closely related to human and social rights (27). Now, this has led some authors to consider mental health as an influential factor in dissocial conduct, and stipulate that this aspect should receive attention in each level of prevention (6).

Likewise, since the psyche is constituted in groupality and is marked by social instances, the system establishes that the basic acquisitions of autonomy, its values and its sense of responsibility should be known. For its part, the Secretariat and the Ministry state that many times the adolescent 
has not achieved the inscription of social norms into his/her psyche, being these those that allow a social coexistence and give an understanding to the meaning of justice (19).

From another perspective, it is found how the United States correlates mental health with dissocial behaviors. In that country, mental health is a risk factor for juvenile delinquency (9). The above is reflected in the high prevalence of mental disorders in the youths involved in the system. This has led the State to implement different levels of mental health care in detention centers. Within their treatment options are cognitive-behavioral interventions and multisystemic therapy, which seek to find causal factors and correlate them with crime and substance use (9).

To complement the above, it is important to highlight what McDermott (28) mentions, since, despite the great need for mental health services within juvenile prisons, prisons do not provide the basic services for young people with disorders, and thus only an increase in their complexity can be expected.

In contrast, mental health and its correlation with criminal behavior is not well established in the Canadian system. The statistics that relate juvenile delinquency to mental health are higher in the adult system. However, the figures found in the juvenile justice system show a great need to better understand the links between mental illness and juvenile delinquency (12).

It should be added that for this country, mental health is understood as a state of well-being in which the person understands his/her own abilities, can deal with day-to-day stress, works productively and fruitfully and is able to make a contribution to his/her community (12). Given this, for Canada mental and emotional health has important implications in the field of juvenile crime prevention, which is why the National Crime Prevention Strategy has programs that implement crime prevention, helping different populations, which include those with mental health problems (12).
How is the mental health dimension addressed by the models?

The SRPA addresses juvenile criminal justice based on measures aimed at the restoration and protection of this population, ensuring their rights and social inclusion $(1,29)$. For its part, Article 103 of Chapter V of the Colombian Constitution addresses the mental health policy for prisons and youth re-socialization centers. It deals with the implementation of psychological and psychiatric care in order to improve the conditions of people with mental disorders confined in Colombian prisons (30); however, no screening or diagnostic measures are proposed.

In contrast to what has been mentioned, Ana Guadalupe Cienfuegos (16) states that the current laws to address juvenile delinquency in Colombia do not contemplate the promotion and prevention of mental health. The problem of this phenomenon goes from being a technical issue that is solved with a punitive intervention to being an issue that requires an understanding of the nature of collective identities and the recognition of delinquent youths as actors with forgotten needs.

In Argentina, the Ministry takes into account that, if there is a mental health problem, articulation actions can be generated with local right protection services. Likewise, if the child responsible for a crime suffers from a mental illness or is addicted to substances, it may be ordered that he/she receive assistance from specialists or that he/she be treated in a suitable establishment (19). With regard to socio-educational measures, the State seeks to provide youths with accommodation in special establishments or sections according to their age, mental psychological development and social adaptability, as needed (20).

Now, according to Jorge Folino (6), from the moment the young person has contact with the judicial system, he/she is treated by mental health experts. An evaluation is carried out for purposes of determining the legal responsibility and to analyze the risk of new crimes to establish what additional services may be required. What 
is sought with this approach is to generate an intervention that respects the right of the young person to health, with the goal of achieving a healthy development. For the system it is important to identify features of cruelty and affective coldness that are observed in young people with characteristics of antisocial risks and increase of violence.

In relation to mental health, Folino (6) believes that the regular intervention of the youths is not necessary, as stated in the article "Juvenile justice system in the province of Buenos Aires and evaluation methods", since the system intends a "normal" approach of the services, which leads mental health professionals to serve more than one institution. However, an effort is made in order to ensure that there are psychologists in each of these.

Now, for the United States, it is imperative that, when talking about medical care within judicial institutions, mental health be included. For this reason, the State has the obligation to provide comprehensive medical care to young people deprived of their liberty (10). However, for many years the courts have implemented a confusing and fortuitous doctrine to evaluate young people who require mental health care (28). Likewise, Christopher Mallet (31) states that the correlation between crime and mental health is sometimes underestimated by the Court and in detention centers.

Several investigations conducted by the United States Department of Justice have documented that the mental health services offered to the youths are, at times, inadequate. However, at the moment there are different types of psychotherapy and psychosocial interventions for the youths reported in the justice system (9).

According to surveys conducted in the United States in 2004 by the House of Representatives Committee on Government Reform, mental health disorders make detainees more vulnerable to prolonged stays. However, although innovative programs have been implemented, surveys continue to show gaps in the availability of treatment facilities for young people with these conditions. Although many of these young people need psychotropic drugs, a large number are being overmedicated and others are underdiagnosed (32).

In Canada, mental health is addressed as an important part of the recovery of young people who have mental illnesses and have committed crimes. The Youth Justice Initiative tries to intervene in all the factors, including mental health (11). The objectives of this juvenile justice initiative are to promote a fair and effective system, to respond to emerging problems, and to allow citizens and the community to participate more in the system.

The Department of Justice of Canada also administers the Youth Justice Fund, a federal donation and contribution program, and the Youth Justice Services Funding Program, which provides financial support to provinces and territories for the delivery of programs and services to youths in conflict with the law. In addition, the program plays an important role in terms of mental health, since the Department finances the provinces and territories for the provision of the Intensive Rehabilitative Custody and Supervision Program (IRCS), which provides specialized resources for the evaluation and treatment of the mentally ill minors in conflict with the law (12).

What kind of interventions are done in mental health?

In relation to the Colombian system, no specific interventions were found in the way of addressing the mental problems that young people linked to the SRPA may have. However, the system is very clear in involving the family of the victim and the aggressor in any judicial process that may lead a minor to the commit a crime, since the purpose of the law is to provide satisfaction and protection of all the rights of children in a comprehensive and timely manner, always allowing restoration and rehabilitation (24). This is done with the purpose of guaranteeing that every child and adolescent has an appropriate physical and mental development that allows $\mathrm{him} /$ her to be an active part of Colombian society (1). Likewise, the system takes into account the 
principle of shared responsibility for pedagogical, protective and restorative purposes.

Among the proposed interventions are admonition, imposition of rules of conduct, community service, assisted freedom, internment in semi-closed regime and deprivation of freedom in specialized care centers. The latter is for minors between 14 and 18 years of age (23).

For the system, the pedagogical dimension is of vital importance, since it understands the youths as individuals in training. Within its action points, the prevention of conflicts is sought in order to guarantee that minors fully enjoy their rights. Additionally, a restorative and transformative attention is sought, through the awareness the offender should achieve, who explores solutions to the conflict, in order to seek reparation for the victims and the community (1).

One intervention was the one used in a focus group study in the city of Bogotá. That intervention was based on Agnew's General Strain Theory, based on the general idea that if a person is treated very badly, a disorder is generated. As a result, interventionist proposals were proposed such as focusing on programs to prevent juvenile homicide, taking into account the risk factors, the training of members of families at risk in order to solve problems constructively, and the training of parents on the effective way to discipline their children (33).

Another example of intervention was the one carried out in Barranquilla, which reported how the offenders are treated in that city. This allowed us to carry out an intersectoral work with the help of the district and departmental governments that led to the development of the Comprehensive Coexistence and Citizen Security Policy of Barranquilla 2012-2020 (34).

Now, regarding the screening, a study was found that used a tool called CD-CLSR, whose application takes approximately ten minutes, does not require specialized training and can be made by telephone, email or internet. It shows a high sensitivity, so it can help to classify young people with behavioral disorders. It consists of a checklist that produces data that are statistically analyzable, and with this, predictive models of behavior disorders could be developed. It should be noted that the aforementioned screening methods are not included in Colombian legislation and, therefore, their use is neither periodic nor necessary (35).

In direct relation with mental health, Argentina believes that a regular intervention of the youths is not necessary. However, care is taken to ensure that there are psychologists in each of the detention centers (4). In the article "Juvenile Justice System in the Province of Buenos Aires" (6) we found that continuous interventions were carried out in the system, which are aimed more at treating the different risk factors. One of the interventions is to provide the youths with educational and employment opportunities, in order to avoid entering gangs, which are sometimes the answer to the economic problems of minors.

On the other hand, among the techniques to achieve these objectives are corrective education, job training and job offer. At the reception centers, insertion strategies are developed, providing advice and support to the young person and his/her family group. In 2010, a service called Programa Volver ("Coming Back" Program) was implemented, whose objective is social integration. With regard to closed centers, there are youths up to 21 years of age, in which educational services are provided (6).

As for interventions different from deprivation of liberty, there is the implementation of medical or psychological treatment, which could be individual or together with the family. In case a judicial process is needed, the child is given psychological support during this process. Additionally, with regard to precautionary measures, these will be taken after performing a medical-psychological examination and a socioenvironmental study of the minor and his/her family (19).

With regard to the United States system, it is pertinent to mention some of the techniques that achieve a significant change and an improvement in the juvenile penitentiary system. Several studies have shown that cognitive-behavioral interventions have a significant effect on the reduction of criminal behaviors in young people 
Juliana Villanueva Congote, María Camila Jaramillo Bernal, Esteban Sotomayor Carreño, et al.

with depressive and anxiety disorders. This promotes the resolution of problems and provides non-aggressive response strategies (9).

There is also the "Simultaneous Treatment Model", which is adapted to mental health and substance abuse problems. The intervention involves motivational interviews as a method to begin the change. As a complement to this, there is the functional family therapy, which has been shown to reduce the recidivism of young people in punishable behavior. For its part, multisystem therapy has shown a reduction of up to $70 \%$ in criminal behavior, which is why it is constituted as a multimodal approach based on a family approach (9).

For its part, in the Ohio's Cuyahoga Hills Juvenile Correctional Facility it was showed that cognitive-behavioral therapy can be supplemented with yoga and meditation to obtain effective results in pathologies such as depression and anxiety. It also reduces the insomnia and pain that are found in posttraumatic stress disorders. These alternative therapies lead the youths to consider more adaptive and cautious behaviors that allow them to contemplate the consequences of their behavior (36).

An example of screening is the one used in Indiana detention centers that use the MAYSI-2 (Massachusetts Youth Screening Instrument, version 2) (37). It is a disorder screening tool that is used during the first 24 to 48 hours after the admission of a minor. Its goal is not to achieve a diagnosis, but to create a report to alert staff to the presence of an individual who shows symptoms that require a mental health follow-up. It should be mentioned that one of the shortcomings of this system is that it varies significantly from urban to rural centers, where it is necessary to obtain a more local mental health care (38).

Regarding interventions, a meta-analysis conducted by the University of Amsterdam, which mainly included studies from the United States, showed that the intensity of the programs is related to their effectiveness. It was reduced when the number of sessions per intervention increased, which suggested that intensive sessions could be counterproductive (39).

For its part, the Canadian system, which has the "Intensive Rehabilitative Custody and Supervision" program, aims to contribute to the delivery of specialized therapeutic services for young people with mental health problems who have committed violent crimes. This program only operates for provinces and territories, that is, it does not apply to individuals or groups (12).

With this program, which has been in operation since 2003, a new option for a therapeutic sentence is established under the Youth Criminal Justice Act for young people suffering from mental, psychological or emotional disorders. Young people with mental health problems who are convicted for the third time for a violent crime in whose commission they caused or attempted to cause serious bodily harm and for which an adult would be sentenced to more than two years can also be subject to an IRCS order. The IRCS funding program provides ongoing financial assistance to provinces and territories to ensure they have the necessary capacity to evaluate and treat sentenced youths (12).

The funds available for specialized treatment in the juvenile justice system are approximately 11 million per year. This is in order to provide rehabilitation and reintegration into society, thus reducing recidivism in violent acts and contributing to public safety. The activities may include IRCS reports and evaluations (12).

A good example to illustrate how the Canadian system operates is the review of the challenges that the province of Quebec has gone through, which is based on the International Convention on the Rights of the Child. The article "The Challenges of a Real Youth Justice System: A Psychoeducational Perspective" (40) establishes the challenges that this province system has faced in order to be comprehensive and give the youths the best resources for rehabilitation from a psychoeducational perspective. All this is based on a system that understands that the best way to protect society will always be through rehabilitation and prevention of recidivism, 
which is what is established at the federal level (40).

\section{Conclusion}

In recent years there has been a change in the paradigm of how juvenile delinquency is understood. Currently, cases are dealt with in a more comprehensive manner, in which the young offender, the Government and, on occasions, the family environment of the offender and the victim participate in the process. Likewise, juvenile delinquency has begun to be understood as a multifactorial phenomenon with different areas of intervention, in which family and social conditions stand out.

In addition to the above, a similarity was found in the way that offenders are prosecuted in Colombia, Argentina and Canada. These countries are based on a restorative justice that seeks to provide reparation and not punishment of the victim; therefore, none of these countries incurs totally punitive measures. These countries understand juvenile delinquency as a social problem, which is the product of the absence and fragility of the State or family nuclei, which triggers conditions conducive to crime. Therefore, they seek to restore the youths through education and integration, trying to intervene in the multiple factors that influence the recurrence of the phenomenon. These three systems consider that the best way to protect society and its inhabitants will always be through rehabilitation, restoration and prevention of recidivism of the offenders.

For its part, the United States system is aimed at punitive justice that focuses on the perpetrator. Although the participation of mental health professionals in the process of each juvenile offender is clear and the restoration measures are evident, the main purpose of the system is to punish the minor offender and to avoid recidivism as much as possible..

After reviewing what was understood and implemented by the Colombian State, difficulties were encountered when carrying out mental health interventions, as well as screening interventions for psychiatric illnesses that may be found in young people linked to the system. In view of this, it is important to raise points of psychiatric intervention, such as the implementation of mental illness screening, with the purpose of improving the management and approach of mental health in young Colombian offenders.

Early prevention is vital through the management of social, cultural and educational risk factors that affect young people and predispose them to commit criminal acts. Within these factors the prevention of all types of violence including family, gang-related and warlike violence, should be emphasized, since these factors have been related to psychological disorders, and are considered risk factors by some judicial systems.

It is important to conduct campaigns to promote a healthy coexistence, with the purpose of recovering these minors who already have risk behaviors. In this way, it would be sought that these youths abandon the use of substances and aggressive behaviors and enter a program of social reintegration where a psychiatric evaluation is made with the purpose of detecting and diagnosing mental illnesses that can be an additional risk factor for juvenile delinquency.

Finally, we think that the group in charge of evaluating minors in penitentiary centers should be formed not only by a psychologist, but also by a psychiatrist, since both professions are important for the comprehensive management of juvenile offenders. In this way the reasons why the minor committed such offences could be understood. Similarly, the possibility of carrying out an adequate follow-up of rehabilitated youths is raised, with the aim of ensuring that they do not fall back into risk behaviors.

\section{References}

1. Ministerio de Justicia y del Derecho de Colombia. Sistema de responsabilidad penal para adolescentes, hacia la protección 
integral y la justicia restaurativa. Bogotá: Ministerio; 2015.

2. Ley 1098 de 2006, del Código de la Infancia y la Adolescencia [Internet]. 8 de noviembre 2006. Available from: https://www.icbf.gov.co/cargues/ avance/docs/ley_1098_2006.htm

3. Decreto 2737 de 1989, del Código del Menor [Internet]. 27 de noviembre de 1989. Available from: https://www.icbf.gov.co/cargues/ avance/docs/codigo_menor.htm

4. Ley 1098 de 2006/8 de noviembre, por la cual se expide el Código de Infancia y la Adolescencia [Internet]. Diario Oficial 46.446 del 08-11-2006. Available from: https://www.icbf.gov.co/cargues/ avance/docs/ley_1098_2006.htm

5. Instituto Colombiano de Bienestar Familiar. Justicia restaurativa, víctimas y sociedades en el sistema de responsabilidad penal para adolescentes [Internet]. Bogotá: ICBF; 2013. Available from: http://www.icbf.gov.co/portal/pa ge/portal/Observatorio1/Archivo/2012 /publicacion-28.pdf

6. Folino JO, Lescano MJ, SánchezWilde A. Sistema de justicia juvenil en la provincia de Buenos Aires y métodos de evaluación. Univ Psychol. 2012;11(4):1065-79.

7. Ley 13298 del 2005, de la Promoción y Protección Integral de los Derechos de los Niños (Argentina) [Internet]. Available from: http://www.gob.gba.gov.ar/legisl acion/legislacion/l-13298.html

8. Skorobogatov Y. How a teenager sentenced to life in prison became the involuntary face of reform. Time [Internet]. 2015 jul 21. Available from: http://time.com/3949836/barney -lee-prison-reform/
9. Underwood L, Washington A. Mental illness and juvenile offenders. Int J Environ Res Public Health. 2016;13(2):228.

10. Office of Juvenile Justice and Delinquency Prevention [Internet]. [Citado 2017 feb 7]. Available from: h ttps://www.ojjdp.gov/

11. Departamento de Justicia de Canadá. Síntesis y contexto de la Ley sobre el Sistema de Justicia Penal para Adolescentes [Internet]. 2015. Available from: http://www.justice.gc.ca/eng/cj-j $\mathrm{p} / \mathrm{yj}$-jj/tools-outils/sheets-feuillets/pdf/s pan/summ-back_spa.pdf

12. Department of Justice Canada [Internet]. [Citado 2017 feb 7]. Available from: http://www.justice.gc.c a/eng/

13. Castellanos Castañeda G, Acero González ÁR, Escobar Córdoba F. Factores de riesgo para violencia y homicidio juvenil. Rev Colomb Psiquiatr. 2007;36(1):78-97.

14. Campo-Arias A, Oviedo HC, Herazo E. Prevalence of mental symptoms, possible cases and disorders in victims displaced by the internal armed conflict in Colombia: A systematic review. Rev Colomb Psiquiatr. 2016;43(4):177-85.

15. Libreros Ortega D, Asprilla Lara Z, Turizo Arzuza M. Líneas de acción para prevenir y controlar la delincuencia juvenil en comunidades vulnerables de Barranquilla-Colombiay su área metropolitana. Justicia Juris. 2015;11(1):40-51.

16. Cienfuegos AG. Lo político y las políticas de la delincuencia juvenil: Una reflexión sobre el caso de jóvenes vinculados al Sistema de Responsabilidad Penal Adolescente. Bogotá-Colombia. De Prácticas y Discursos 
[Internet]. 2015;4(4). Available from: http://ppct.caicyt.gov.ar/index.p $\mathrm{hp} /$ depracticasydiscursos/article/view/7 $277 / 6577$

17. Betancur C, Restrepo-Ochoa D, Ossa Y, Zuluaga C, Pineda C. Representaciones sociales sobre salud mental en un grupo de profesionales en la ciudad de Medellín: análisis prototípico y categorial. Revista CES Psicología. 2014;7 (2):96-107.

18. Acosta M. Adolescentes con comportamientos delictivos de los municipios de Rionegro, Marinilla y La Ceja: Algunas características para su comprensión. Kénosis [Internet]. 2015;3(5):14-27. Available from: http://revistas.uco.edu.co/index. php/kenosis/article/view/71

19. Secretaría de Derechos Humanos de la Presidencia de Argentina. Justicia restaurativa en el sistema de responsabilidad penal juvenil: Conceptos, perspectivas y mecanismos procesales para su implementacion. En Derechos de niños, niñas y adolescentes. Buenos Aires; 2010. p. 1-211. Available from: http://www.jus.gob.ar/media/112 9109/17-dhpn-justicia_restaurativa_e n_el_sistema.pdf

20. Knight D, Belenko S, Wiley T, Robertson A, Arrigona N, Dennis M, et al. Juvenile justice-Translational Research on Interventions for Adolescents in the Legal System (JJTRIALS): A cluster randomized trial targeting system-wide improvement in substance use services. Implementation Science. 2015;11(1).

21. Rapp L. Delinquent-Victim youth-adapting a trauma-informed approach for the juvenile justice system. J Evidence-Informed Soc Work. 2016 Sep 2;13(5):492-7.

22. Ministerio de Salud y Protección Social. Abecé sobre la salud mental, sus trastornos y estigmas [Internet]. 2014 [citado 2017 feb 22]. Available from: https://www.minsalud.gov.co/sit es/rid/Lists/BibliotecaDigital/RIDE/VS /PP/abc-salud-mental.pdf

23. Instituto Colombiano de Bienestar Familiar. Los adolescentes en el sistema de responsabilidad penal para adolescentes. Bogotá: Instituto; 2013.

24. Instituto Colombiano de Bienestar Familiar. La familia en el sistema de responsabilidad penal para adolescentes. Bogotá: Instituto; 2013.

25. Vergara Quintero MC. Representaciones sociales sobre salud, de algunos grupos de jóvenes de Manizales, Colombia. Rev Latinoam Cienc Soc Niñez Juv. 2009; $7(1): 105-33$.

26. Uribe Aramburo N. Problemas del tratamiento legal y terapéutico de las transgresiones juveniles de la ley en Colombia. Pensam Psicol. 2009;6(13):173-91.

27. Ley Nacional de Salud Mental N. ${ }^{-}$26.657, Argentina [Internet]. Available from: http://www.msal.gob.a $\mathrm{r} /$ saludmental/images/stories/info-equi pos/pdf/ley-nacional-salud-mental-26. 657.pdf

28. McDermott S. Calibrating the Eight Amendment: Graham, Miller, and the right to mental healthcare in juvenile prison. UCLA L Rev. 2016;63(3):712-59.

29. Instituto Colombiano de Bienestar Familiar. Instituciones del Sistema de Responsabilidad Penal para Adolescentes. Bogotá: Instituto; 2013.

30. Ley 1453 de 2011/24 de junio, por medio de la cual se reforma el Código de Procedimiento Penal, el Código de Infancia y Adolescencia, las reglas sobre extinción de dominio y se dictan otras disposiciones en materia de seguridad [Internet]. Diario Oficial 
48.110 del 24-06-2011. Available from: http://www.secretariasenado.gov .co/senado/basedoc/ley_1453_2011.ht $\mathrm{ml}$

31. Mallett C. Youthful offending and delinquency: The comorbid impact of maltreatment, mental health problems, and learning disabilities. Child Adolesc Social Work J. 2014; 31(4):369-92. doi:10.1007/s10560-013-0323-3

32. Cohen E, Pfeifer J, Wallace N. Use of psychiatric medications in juvenile detention facilities and the impact of state placement policy. J Child Fam Stud. 2012;23(4):738-44.

33. Escobar-Córdoba F, AceroGonzález Á, Folino J. Homicidas juveniles en Bogotá, estudio de grupos focales. Rev Fac Med. 2015;63(3):389-98.

34. Valdés R, Amador E. Políticas públicas y marco jurídico para prevenir y sancionar la delincuencia juvenil en Barranquilla. Pensamiento Americano. 2013;6(11):27-50.

35. Pineda D, Kamphaus R, Restrepo M, Puerta I, Arango C, Lopera $F$ et al. Screening for conduct disorder in an adolescent male sample from Colombia. Transcult Psychiatry. 2006;43(3):362-82.

36 . Williams $L$. The value of alternative therapies in mental health treatment for incarcerated youths. Corrections Today. 2016;78(1):24.

37. Aalsma MC, Schwartz K, Perkins AJ. A statewide collaboration to initiate mental health screening and assess services for detained youths in Indiana. Am J Public Health. 2014;104(10):e82-8.

38. Aalsma M, White L, Lau

K, Perkins A, Monahan P, Grisso T. behavioral health care needs, detention-based care, and criminal recidivism at community reentry from juvenile detention: A multisite survival curve analysis. Am J Public Health. 2015;105(7):1372-8.

39. Vries SA, Hoeve M, Assink M, Stams GM, Asscher JJ. Practitioner review: Effective ingredients of prevention programs for youth at risk of persistent juvenile delinquencyrecommendations for clinical practice. J Child Psychol Psychiatry. 2015;56(2):108-21. doi: 10.1111/ jcpp. 12320

40. Dionne J, Altamirano C. Los desafíos de un verdadero sistema de justicia juvenil: Una visión psicoeducativa. Univ Psychol [Internet]. 2012;11(4):1055-64. Available from: http://www.scielo.org.c o/pdf/rups/v11n4/v11n4a02.pdf 